University of Louisville

ThinkIR: The University of Louisville's Institutional Repository

Electronic Theses and Dissertations

1937

\title{
Cooling of a hydrocarbon oil.
}

Edward Groth

University of Louisville

Follow this and additional works at: https://ir.library.louisville.edu/etd

Part of the Chemical Engineering Commons

\section{Recommended Citation}

Groth, Edward, "Cooling of a hydrocarbon oil." (1937). Electronic Theses and Dissertations. Paper 1801. https://doi.org/10.18297/etd/1801

This Master's Thesis is brought to you for free and open access by ThinkIR: The University of Louisville's Institutional Repository. It has been accepted for inclusion in Electronic Theses and Dissertations by an authorized administrator of ThinkIR: The University of Louisville's Institutional Repository. This title appears here courtesy of the author, who has retained all other copyrights. For more information, please contact thinkir@louisville.edu. 


$$
\begin{aligned}
& \text { : } \\
& \text { ㄴ. }
\end{aligned}
$$

COOLIHe OF \& FrDBoCLRBOH OIL

\author{
1 Theols \\ Submitted to the Paculty \\ of the Graduate School of the Oniverolty of Loul orille \\ in Partial Fulfillaent of the \\ Bequirements for the Degres of \\ Lastor of Chenloal snglnoering
}

Department of Chenical Buglneering

by

IBdward Groth. Ir.

1937 
Edward Groth, Jr.

coolite of a morocarbor oIt

Director:

Approred by

Reading Cormittee:

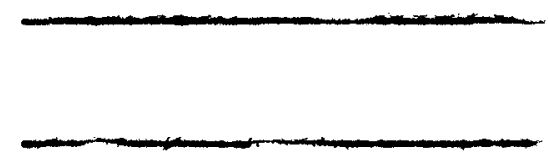

Date:

Angust 7. 1937 


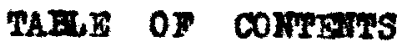

$$
\text { Page }
$$

List of Pabies 2

Il st of Curres 2

List of IIInstrations 2

List of Smbola 3

Leknowledgenent

4

I. Introduction 6

II. Apparatus and Katerials 18

III. Txperimental Fork 26

IV. Concluatons 39

Bibliography

42

Appendix

4 


\section{LIST OP TABLS}

\section{Page}

Table I Physical Propertles of Bocene 25

rable II Heat Tran ofer Date 28

Pablo III Di atillation Ranges of Bocene 45

\section{IIST OF GURTES}

Curre I Comparison of Data with Iristing Bapirical Equetions 38

Curre II Varlation of Viscosity of Bocene I1 th Temperature $\quad 46$

\section{LI3F OF ILLUSTRATIONS}

Hgure I Heat Bxchanger and Lccessories 15

P1gure II Heat Inchanger 17

PIgare III Amonia Compregser 19 
LIST OP SMBOLS

Symbol

4 Heat transfor surfaco

$\mathbf{C}_{\mathbf{p}}$

D

6

h

$\mathbf{k}$

$x$

Q

$\mathbf{t}$

$t_{1}$

$t_{2}$

$t_{3}$

4

V

W

8

at

$P$

$\mu$
Quentity

spoelfic heat

Dianeter of plpe

Mass rolocity

Heat tranaf er coofficlent

Thermal conductirl ty

Length of tert section

Quantity of haat transforred

Average plpe temperature

pegt liquid entrance temperature

Test liquid exit temperature

Refrigerant entrance temperature

Refrigerant exit temperature

Velocity of test Ilquid in pipe

Wel rate of flow

Viscosit ty

Temperature difference

Density of riudd

Fiscodt of rluid
Dnits

8q. $f t$.

B.T.0./(hr. $)\left({ }^{0}\right.$.. $)$

It.

$\left.1 b_{s . /} / \mathrm{hr}_{\mathrm{H}}\right)(\mathrm{aq} \cdot \mathrm{ft}$.

B.T.U./(hr. )( ag. et. $)\left({ }^{\circ} \mathrm{F}.\right)$

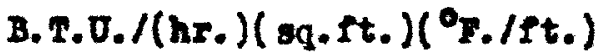

rt.

B.T.U./hr.

\%.

P.

OP.

\%.

OF.

st. Mr.

Ibs./hx.

centipol seo

${ }^{7}$.

Ibs./cu. It.

lbs./(et.)(hr.)

Symbis are from the stem recomended by the councll of the American Instltute of Chenlcal Bnglneers. 


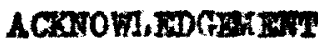


The euthor of this thesl s wishes to acknowledgo the assistance, argestions, and eriticisas of Dr. R. C. Brnat. who directed this resenrch. 
I. IXTHODUCTOK 
The purpose of thi o inveatieation was to study the tranemisot on of heat in a liquid-11quid hest exchanger in regions of $\mathrm{r}$ seous and critical flow and at teaperatures in the reglon of $32^{\circ} \mathrm{z}$. The apperimental work was carried on under conditione approaching industrial practlce. so that the reauls would be userva in the desien of pructienl coolers, erystallizers, and rofrigerating unts.

The fluld used in this Investigation was "Bocene", a high grade of kerosene. The heat exchanger was deshened by Browne ane Finger. (1) from the plans of J. F. D. Snith (10), and built by Browne (2) and Donaher (3).

Prewious invest1gators (5-10) haro correlated sinilar heat trangfer data by use of a form of the Ruselt equation:

$$
\frac{m}{x}=\left(\frac{D G}{\mu}\right)^{n}\left(\frac{\cos }{x}\right)^{m}
$$

were $a, n$, and $a$ are constants and the other terms are defined in the Il st of sumbols, page 3. This eguation Involves three dimensionless groups. i. e.. the Iraselt number. (hD/k), the Regnolds number. (DC/ $\mu$ ). and the Prandtl mmber. $\left(C_{p} \mu / x\right)$, and 11 lugtrates the $n$ ge of dimenalonal analy a for the correlation of heat trangfer data. Int a method is aved as a convenient way of relating and correlating data wore many rariables are inrolred. Fariables encountered in heat trangrer of this type are the riscosity. specifle leat, density, and themal conductivity of the fluld, the dianeter and lemgth of the pipe, and the relocity with wich the fluid flows through the pipe.

of the three dimensionless Eroups, the Beynolds number. (DO/ $\mathrm{C}$ ). Is one of the noot frequently occurring in fluid drnanics and hoat trangfor. and indlcates the degree of tarbulence of how. Wth a single 
flusd flowing in a pipe of constant dianeter, the dengl ty and riscost are oubstantialls constant, and the controlling factor is soen to be the relocity of Now. For ralues of the Rarnolds muber below 2100. the flew Is considered riseons or gtreanilne, while for ralues above 4000. the flom 1s called turbulent. The intermediate region is called the critleal recion, and is a transient zone in which the flow may hare the characteristics of al ther of the two topes.

The Prandtl number. $\left(G_{p} \mu / x\right)$. 1 s obtained from the phy olcal properties of the fluid Itself- specific heat. riscosity. and thermal conduct1rity. These properties are nearly constant oror onall ranges of teaperatures. so the magnt tude of the Prandtl number will bo found to change but 21ttlo during investiention of a single wsten. Its magnl tude w11 chanee chierly as the complexity of the of sten is increased. That 1s, the value of the PrandtI naber wII Inerease in passing frem a gan of th a dmple molecule to a gas dth a complex molecule. then to water and aqueous solutions. and then to olls and organic 11quids. As preriougly stated, the Prandtl maber renains almost canstant in the investigation of a single fluid, and thus could be coltted entirely. or replaced by a constant in the masaelt equation. 1 thout any appreciable orror. Its inciugion is required in order that a Eeneral relation may be shown, and in order that a compari ion w th data on other stems may be obtained.

The Thaselt maber. $(\mathrm{hD} / \mathrm{k})$, containg the film coefficient. the pipe dianeter, and the themal conductivity of the Muld. In a single experiment, were the pipe diemeter and the conductivity remain constant. the magnitude of the Fusselt number $1 \mathrm{~g}$ dependent entirely 
on the film coefficient. Since the coefficient is derined as $h=k / t$. where $k$ is the themal conductivity and I 1 s the thickness of the $f 1 I m$. the magnitude of the coefflctent is dependent entirely on the thictoness of the flin. This thicleness is Influenced by sereral factors, IncludIng the relocity of flew. the density of the fuld, the riscosity of the fluld, and the smoothness of the Inner surface of the metal mil. The trabulence realting from a M gh reloct roduces the fill thickneas. while a high denst al we tends to bring about the same reart. The 11m thickness is 21 so Innuenced by the huld viscost ty. especially at the temperature of the film. The thickness of the film bears a direct relation to the $\mathrm{r}$ iscogity- a high $\nabla 1$ seosity prodnces a thiek file. whilo a tuin film accespanies a low viscosty. Lagtig, the thickess Is Infunenced by the snoothness of the metel pipe. A roughness of the surface has been show to increase the effective filn thicknese. 20 the three groups in the equation, a fourth- $\mathrm{X} / \mathrm{D}$, the ratio of trube length to diameter- has been added by sereral investigators. Yaldang and Frost (4), after analy sl of varlous data on hoating water In tubes in wich the $\mathrm{K} / \mathrm{D}$ ratlo raried frem 34 to 100 , found an apparent effect of tube lenctix, and proposed the equation:

$$
\frac{\mu p}{z}=0.0272\left(1+\frac{50 D}{Z}\right)\left(\frac{p e}{\mu}\right)^{0.8}
$$

The ealsalon of the Prandtl number was compen sated for to certaln extent by the use of the visosity. $\mu_{f}$, at the mean film temperature. Howrer, Iarrence and sherrood (5) found the length to hare a negligible effect, al though their investigation corered a range of lengths equivalent to 59 to 224 diameterg. The data on wator obtainod by Lawrence and Sherwood wore found to be reasonably well correlated 
by the equation:

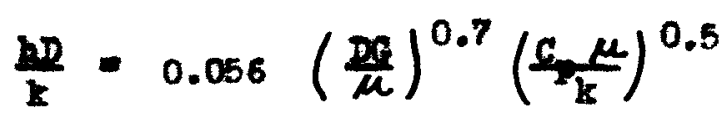

Uorris and mituan. (6). after a study covering the heating and coollng of water and sereral oflo, proposed a value of 0.37 as the exponent of the Prandtl nuber, and prosented thoir corrolation graph-

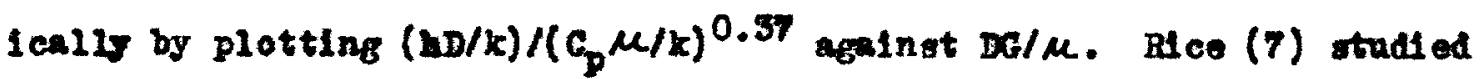
the date of sereral provious investlgators on fluids ranging fros alr and simple gages throuch water and olls, both in heating and cooling. He eirot propoed the equation:

$$
\frac{m_{1}}{k_{p}}=\frac{1}{63}\left(\frac{\mathrm{ng}}{\mu_{f}}\right)^{0.83}\left(\frac{\mathrm{c}_{\mathrm{e}} \mu_{f}}{\mathrm{k}_{f}}\right)^{0.5}
$$

were the physlcal properties of the Mutd are all taken at the arithmetlc mean film temperature. He later modified the original equation to:

$$
\frac{h_{2}}{k_{p}}=\frac{l}{60}\left(\frac{D_{f}}{\mu_{p}}\right)^{0.83}\left(\frac{\varepsilon_{1} \mu_{p}}{k_{f}}\right)^{0.33}
$$

After extended stady of date on water and al $r$, and the Horrs s and hitwan date on o11s. Dttus and Boelter (8) In 1930 proposed two equation: to be asod in the correlation of data on heat transfer:

$$
\begin{aligned}
& \text { for henting. } \frac{M}{L}=0.024\left(\frac{M G}{k}\right)^{0.8}\left(\frac{G \mu}{k}\right)^{0.4} \\
& \text { for co011ng. } \frac{h n}{k}=0.026\left(\frac{D G}{\mu}\right)^{0.8}\left(\frac{G}{k}\right)^{0.5}
\end{aligned}
$$

Two years later. Sherwood and Petrie (9) presented date on heat transfor to water, acetone, bensene, keresene, and $n$-butyl alcohol in both

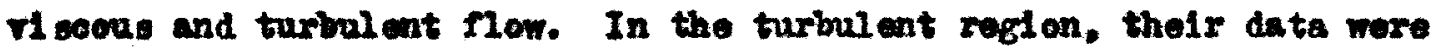
found to be in excellent agxesent ith the enplateal pittur and Boeltor equation, bat the egrement of polnts in the riscous and critical 
reglons was not rewy clove. The observed, beverer, that the slope of the keresene line in and sifhtl abore the critical regi on wa: "definitoly exeater" than 0.8. Since wost of thelr woric was done in the turbulent region, the dats on 1 scous $n$ or were not extengire enough to warreat a general conclusion. A drect compari son w th the equation was ude by plotting $(h D / k) /\left(c_{p} \mu / k\right)^{0.4}$ agalnst $D E / \mu$. In 1935 . Sal th (10) preseated Ainilar data on hrdrocarbon o11s, and al so cadorsod the Dittus and Boelter equation as oultable for corrolating heat trangfer data in turbulent flow. Ho al 80 plottod $(\mathrm{kD} / \mathrm{c}) /\left(\mathrm{C}_{\mathrm{p}} \mu / \mathrm{K}\right)^{\mathrm{n}}$ ageinst $\mathrm{DG} / \mu$. uelng $\mathrm{m}=0.4$ fer heating and $\mathrm{a}=0.3$ for cooling rang.

In correlation of $\mathrm{r}$ scovs $\mathrm{Now}$ data. the Graots nuber. $\left(\mathrm{HC}_{\mathrm{p}} / \mathrm{ha}\right)$. Ie often veed in place of the Reonolds number. After studyIng and recalculating the data of a muber of prevlous investigators. Drow. Hogen, and Uadians (11) concluded that in vi scous flow, wore the heat trangferred by conrection wa neglifiblo conpared wth that trantferred by conduction, a good correlation conld be obtalned by plottine

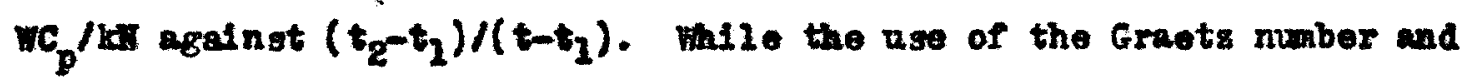
the (temperature-rlse)-(teaperature-difference) ratlo may be otilactory In single case. there is no indlcation that such a correlation wil be applicable over as wide ranges as that satigfled by the Fusvelt equation. Sherwood, K1ley, and rangeen, (12), In working of th oll flow Ing in horisontal pipes, attmpted a correlation by means of the Grats relation. The found, howerer, that the method was inadeguate for the correlation of thol $r$ data. Thay found that a plot of $\left(t_{2}-t_{1}\right) /\left(t-t_{1}\right)$ against DG/M Indieated anden and large increase in the amount of heat transforred as the flow paged from the risoous to the critienl 
and then to the turbulent region. Saith (10) nsed the Grsots relation

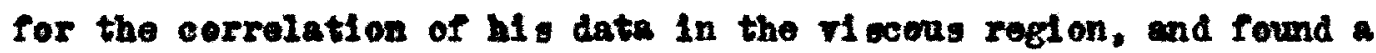
reasonably close agreanent. The correlation in the riscoug regi on wo this mothod was not so gatl afactory. howerer, as that in the turbulent regton. were the Fusselt equation was used.

In the progent imregtigation, heat transenl ssion at Ion relocities and at temperatures belon room temperature will be studied. Parifled kerogene vil be uged as a test 11 quid on the ingd of the pipe, and alse as a refrigerant on the outglde. The data will be compared wth the results of provious investlgators obtained at higher toaperatures. 
II. APPARATUS AID MATHETALS 
4 complete and detalled deseription of the apparatus is given by Browe (2) and Donaken (3). Mgure I, page 15. 18 a Tiew of the canplete heat axehangor. Including the potentlemotor and galvanomotor uged in talding the themocouple readings. Fgare II, page I7, show: the heat exchnger with the part o labeled to eorrespond with the dotall mentloned in the following di veuselon. Figure III. page 19. sows the emonla coupreser which was uned for cooling the refrigorat.

\section{A. Feat Prehanger.}

The test soction is a standard one-inch brass pipe, contalned In a east iron sell. The total length of the brage pipe is aine foot. Ax incher- a tert length of ofx foot precedod by a calning soction of twenty-three inches and followed by an adt section of nineteon inches. The east Iron hell 1 a made of of two inlet and outlet sections for the refrigerant, C 1 and C 2; Ix split gleores, D 1, D 2, D 3, D 4, I I. and 7 2: and two thirty-1noh seeves, 1 and $I 2$. The split aloeres are Installed at the thermocouple junctiong wo that any changes or repal rs an be fac111tated.

Calning section: in the rerrigerant inlet and outlet soctions are provided to prerent turbalence near the themecouple junetions at the pipe ends, and to wake the flow of the refrigerant strocaline efter pa esage through the aixing chombers.

Imer steel sleover prevent the trangfer of heat betwoen the refrigerant and the test IIquid in the refrlgerant inlet and outlet sections. These seares extend through the inl of and outlet soctions to the centers of the ollt east iron aleores, D 2, D 2, D 5, and D 4. the forming an amular opace around each end of the brass pipe. The 
Heare I.

Heat Ioshanger and secesaoriea 


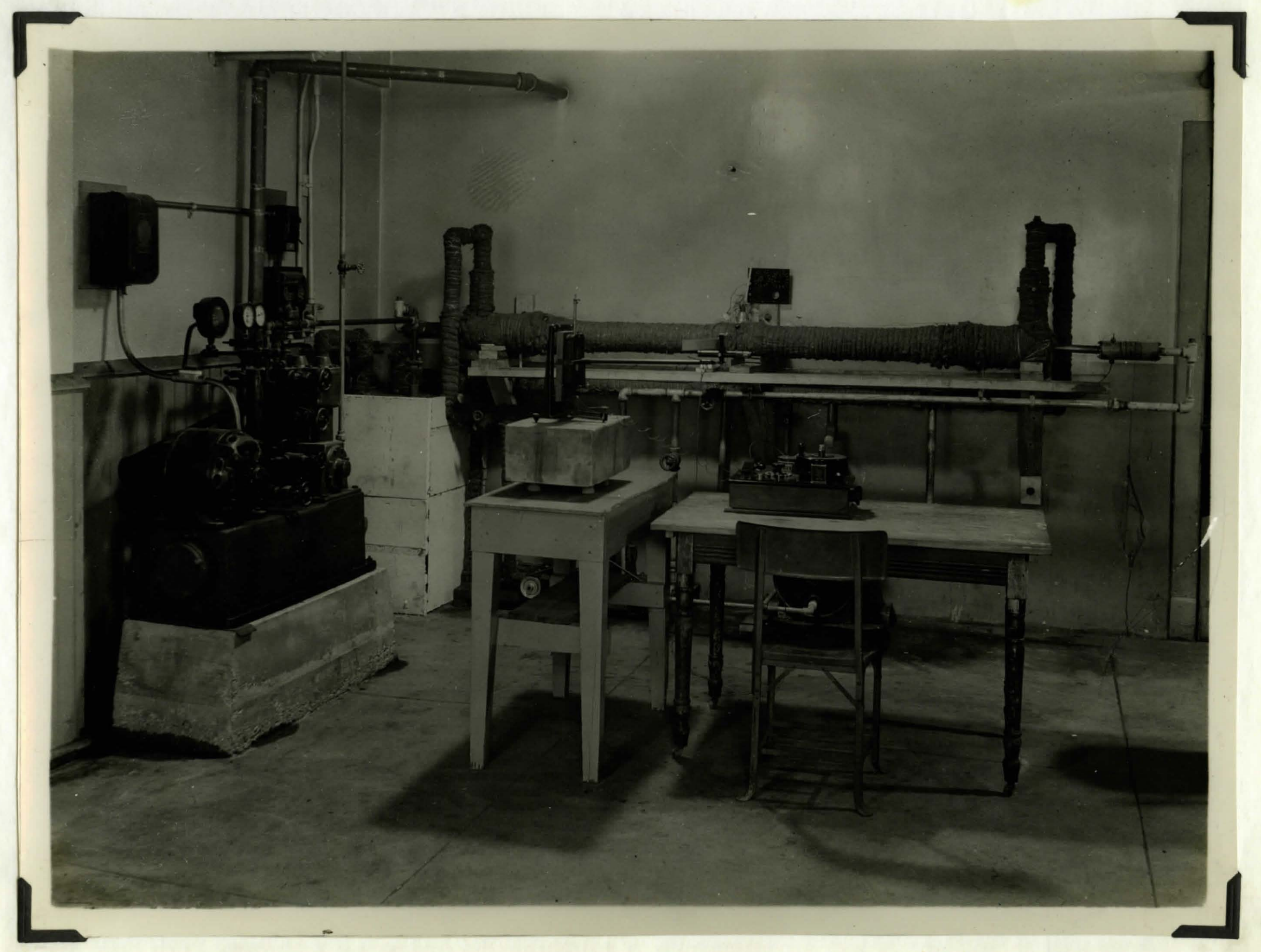


Mgare II.

Heat Dehnnger 


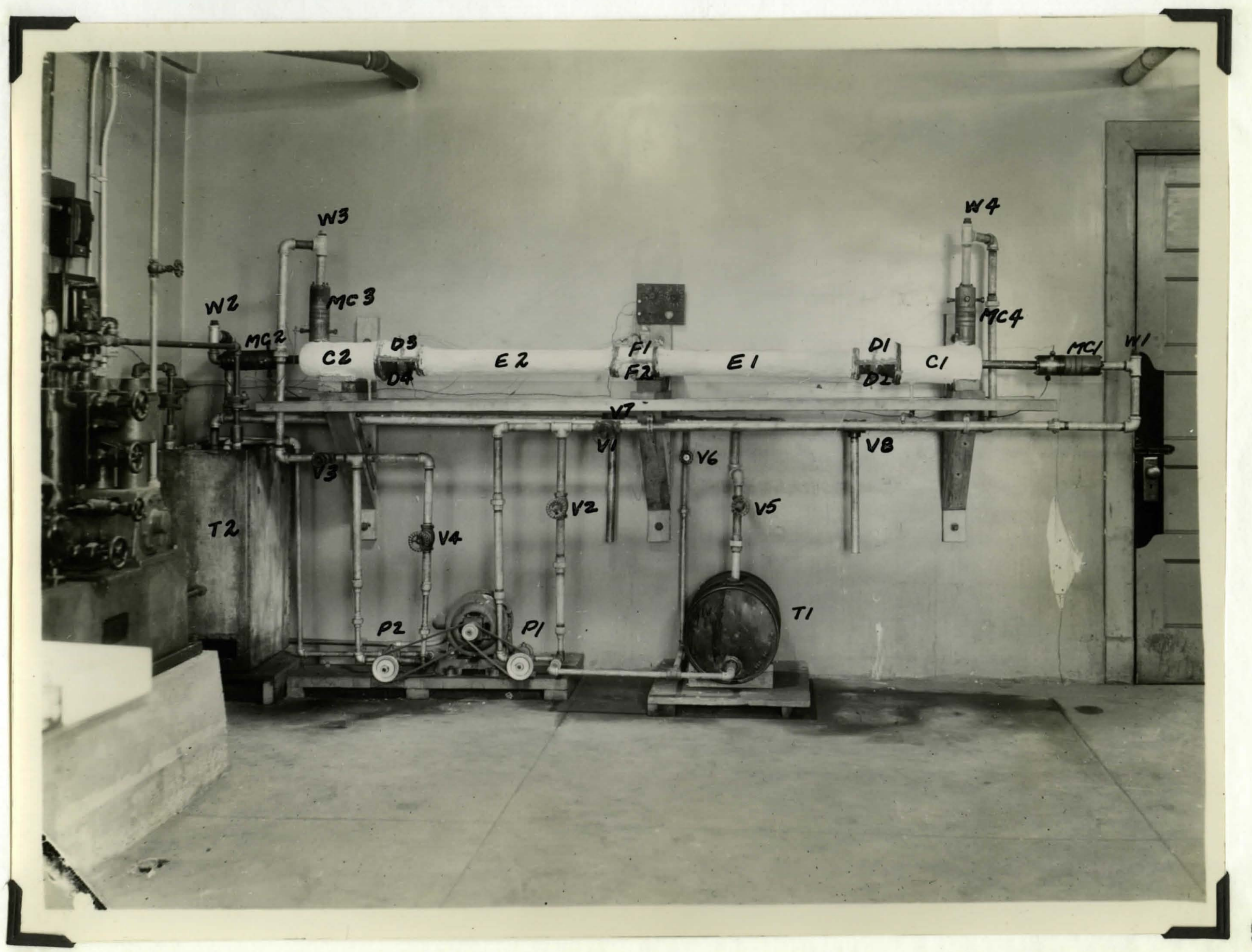


Mgure III.

Amonia Compreseor 


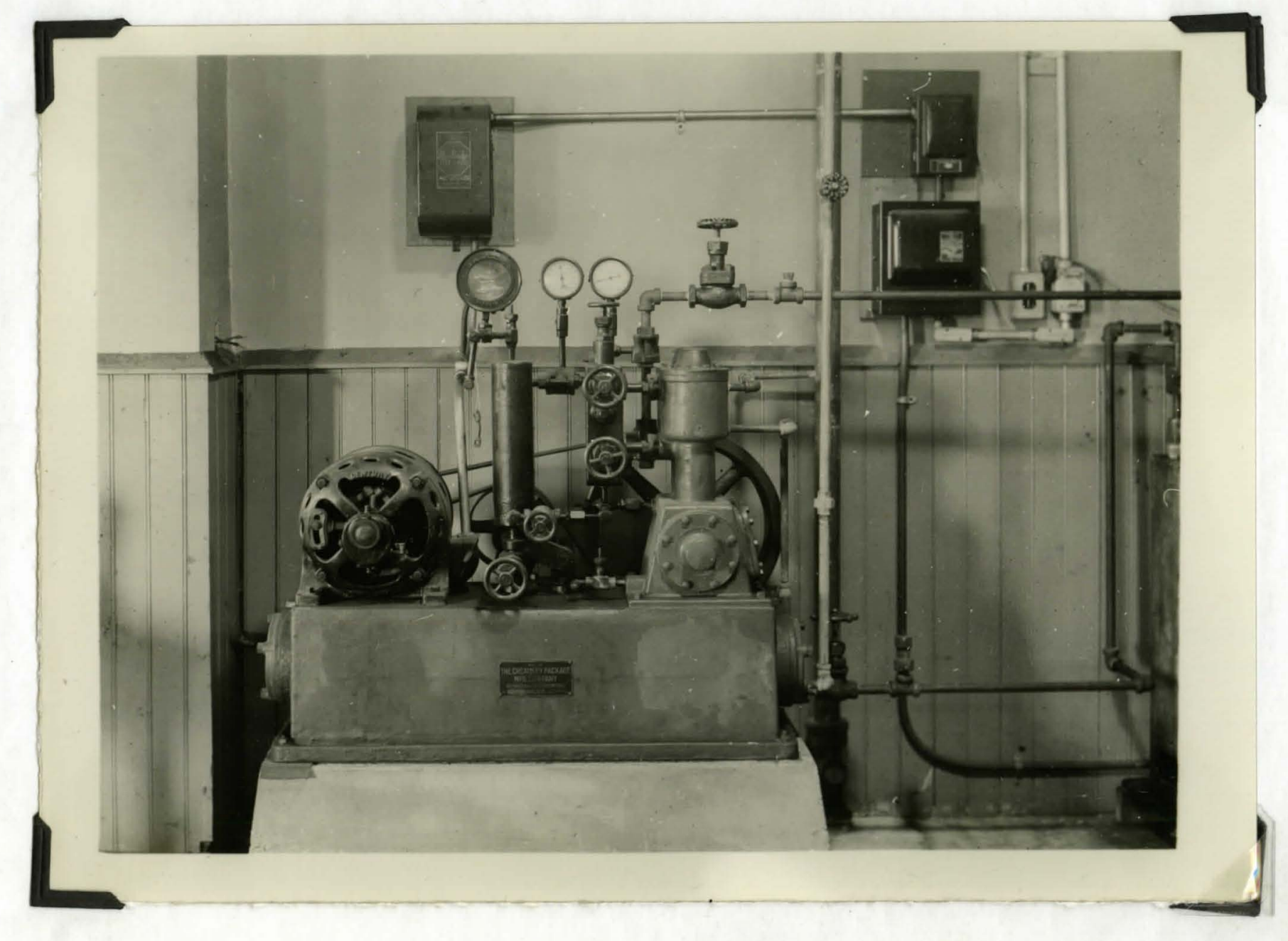


annular spaces are packed ith rock wool, so that heat tran sfor is roduced. and more nearly accurate measarement of temperatures 1 s mado posable.

In order that heat trensf or by conduction botwoen the brass pipe and the cast Iron shell way be minimised, asbagtos strips are placed between the surfaces makine contact. Such conduction transfor 1. of I1ttio importance. Ance areas of contact are sall and relatiraly di stant frem the test ooction.

The alxing chaber are made up of olotted steol and coppor collars bolted togethor. Mang chabers in the test IIquid IIne. KC I and IC 2, and In the refrigerent inlet and outlet 11nes, HC 3 and IC 4. bring about a complete mixdng and uniform pluld tomeratures, so that the teaperature of the entire Muid bod may be monsared by themecouple placed in the center of the etrenn of liquid.

the calning wection $1 \mathrm{~s}$ a crose mode of heot coppor, pleced In alde the bress pipe botwewa the test section and the ming chaber at the catrance and. Ihe calming cross tend to oliminate and turbulence In the plpe that mar resalt from the pasage of the fluid through the wixing ohamber.

Sixtean themecouples are installod in the heat exchangerone 18 pleced in cach of the four aixing chambers, and trelte. In grome of four, are fastened to the brass plpe. The themocouples are made of B0. $28 \mathrm{~B}$ i $\mathrm{S}$ gage Iron and constantan $\mathrm{Are}$, wolded together at one end and carried to a cold junction on a shelf behind the exchanger. Iram the cold junetion, copper leade are run to twe manumls controlled dials w th alxteen terminals. so thet ary themocouple of the group 
may be conneeted to the potentloneter by a proper adjustanent of the dials.

The thermocouples are Installed in the alding chabers through ono-igh th inch copper tubing. ecatered in one-half inch steel bolta. The junctions are lacated in the center of the liquid streen, and are protected by the coppor tube, which extends to $\mathrm{M}$ thin ono-sixteenth Inch of the junction.

The bwelve thermocexples attached to the plpe al oo pags through ono-half Inch bolts in the gplit aleeres, four at each end and four in the center of the test section. Inach group of four 18 egunily spaced around the elrounference of the pipe. Dach junction is soldered to the plpe at one and of a one-dxteanth inch by one Inch alot cut in the pipe. We lots are Pliled with 11 tharge and gircerine coment. and the sarfece is ireased down oren id the sarfece of the pipe.

\section{B. Amenarian.}

Twe roserrelrs are prorided for the refrigerant and the teot 11quid. The tost 11 quid reservolr is a borisental steol drun of tha capacits of ten gallons. I by-pase 11 ne around the reserrolr affords - weans of centrolling the temperature of the liquid paselng through the corehanger. The rofxigorant reservolr 10 a vertical rectangular tank, holding about thirty gallons. The expansion colls of the ammonia compressor are contained in this tank.

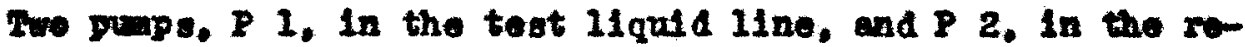
frigerant line, are prorided for the elreviation of the twe Ilquids. the are brense gear paxs, haring a capacity of alx gilions per mimute at apoed of 1000 A. P. K. The pups are driten by a notor, operated 
at constant speed. The rate of flow of refrigerant and test Ilquid is regalated beans of valves $V 1,72,73$, and $T 4$ in the lineg.

The wolfing tank is almply an open contalner, used to collect a portlon of the test llquld orer meacared period of time, for the determination of the rate of Mow. The test 11 quld is taken from the return IIne threaget the three-way ralre, 7.4 Aallar threo-way ralre. 8 , I provided for the deterinination of the rate of flow of

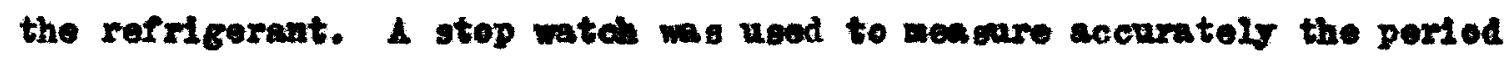
of tIme orer wieh the finid wo collected, when ranged frea thirty to ats geconds.

For the attalment of $10 \mathrm{w}$ temperatures. A three-quarter ton amonie cemprester was Installed, wth the expansi on coll pleced in the refrlgorant rocervelx. The compressor was mamally operated, and the refrigeration was oontrolled ontirely by adjuting a noed o-polnt expenden ralre In the Ilquid amonia 11 ne.

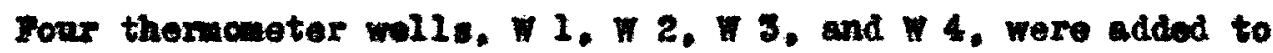
the exchanger to provide a meane for readily determining the conditions of operation, and to rurni a check on the themocouple readings. He wolls are wade of quarter-inch coppor tubing. with a plug brased in one end. The tubling passes through a hole drilled in a standerd oneInch cast Iron plag.

The rofrlgeramt reserrole wa invalated with shoet cort and Celoter, sealed into place wi hot ampalt. Irrogularities in the ourface of the heat axchanger were fllled with asbestos flber puiped Ith water and plagter of parl 8 , and allowed to dry. The exchanger and all the refrigerant IInes were then covered with a layer of halr felt. 
The thermocouple readings were taken with a Leeds and Forthrup

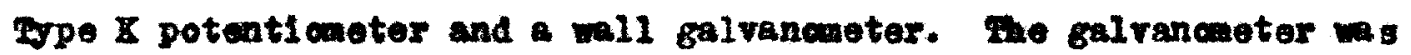
mounted on a heary concrete base, wheh in turn was supported by four rubber cushi ons. In order to eliminate di sturbances tue to ribration.

\section{c. Oneration.}

In the operation of the heat exchanger. the test IIquid is draws from the tank. 2 1. w the puap. P 1. The rate of for is controlled by wanipulation of the ralres, $Y I$ and $T 2$. The tost IIquid flows next through the wxing chmber. YC 1 , and 1 ts teaperatare 18 measured by therwoouple 1. After flewing through the calning soetion It enters the test section, wore its teaperatrare is lowered. Its tepersture is agrin measured by themocouple 2 , after pasaing through the mixding chember, nc 2. Fe test 11 quid is then rotumed to the resorvolr. mere it re-anters the cyele.

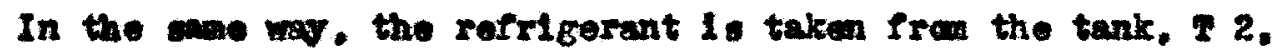
by the poup. P 2, was its relocity regulated by manipulation of the

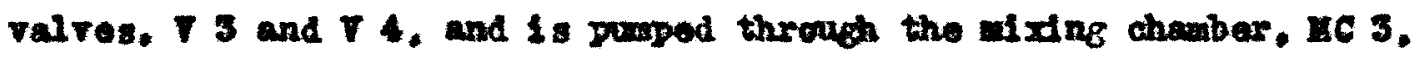
Where It: temperature 1 measured by thensocouple 3. After pasding threagh the anmular space botween brass pipe and the cast iron shell. the refrigerant is mixed in mixing chuber MC 4, has it a temperature mencured by themocouple 4, and is then returned to the tank. 2. to be coeled agrin.

\section{Lateriale.}

The phy gical properties of the zocene nsed in the calculation of the resalts are IIsted in Table I. pee 25. The density was determined experimentally by use of a Wegtphal balance. Sinee the Regnolds 
Table 1

PRYSICAI PROPERTISS OF ROCWV

Density $\left(60^{\circ} \mathrm{F.}\right) \quad 50.1 \mathrm{lbs.} / \mathrm{cu} . \mathrm{It}$.

Spoelfle hoat

0.504 B. T.0.1(2b. $)\left({ }^{\circ} \mathrm{F}.\right)$

Themal conductirity

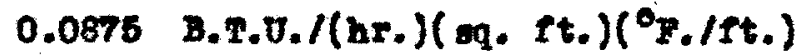

(Distillation ranges and a tewperatare-ri sco si ty curve are inciaded In the eppendix.)

number was calculated diroctly froe the weleth rate of flow, no esemptions of a constant donat ty were made. The specifle neat was determined by measuring the Increase in tenperature of a knom weight of Bbcene. brought about by the introduction of a measared quantity of eloctrict by. The heatine wa accoapli bod in a ball themos bottle. uging a nichrome heating ol enent: an electric stirrer insared cenplete wine during the beating. Fi seosties wore dotemined at sereral temperatures using a Heopler riscosimeter. and a mooth curre was dram to show the rariation of the $r$ ecesity of th a change in temperature. The ralue of the thereal concuctivity was taken as ropresentative of sereral found in the ilterature. 


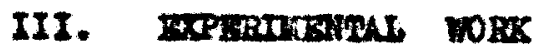


Prior to obtaining data, the refrigerant was cl roulated in the wit ant11 the apparatas wa thoroughly cooled. Mil generally required about six to olgt heurs. The cooling was followed br efrculation of the test huld nat1l equllibrim conditions had boen attalned. Conditione of steady state heat transfer ware indicated by constant test IIquid and refrlgerant entrance temperatures, and usully were established in from fifteen minutes to two hours, depending on the rate of flew of the teat IIquid.

Wuen equilibriue had been resched, the cold junctions of the themocouplos wore adjusted to exactly $32^{\circ} \mathrm{F}$. In an 160 bath. The potentlometer efreult as balanced egalast a standard cell, and the themocouple teaperatures vere deternined and recorded. The four thermoneters in the thermeneter wells were read and their tanperatures 11 kew se were reeorded. After all the temporature readings hel been taken. a portion of the test Ilguld wa collected. usaally orer a perlod of thirty seconds, and weighed. Then this sample had bean returned to the teat Ilquid reservolr a now rate of flow was obtalned by regulation of the ralres, and operation was contluned until equilibrion conditions were again attainod. Fyrorully adjustine the valres, it was posable to obtain ofent to ten sots of date between the minimum and endinum rates of flow.

The experimental data and the calculated revalts are containod In rablo II, pages 28-35. The test 11quid Inlet and outlet temperatures are recorded Afretly as deternined by the themocouples. We arerage plpe temperature is the temperature correspending to the average willvolt reading of the twelve thexrecouples on the pipe. Other Invertigaters 
Table II

HEAT TRISFIA DAT

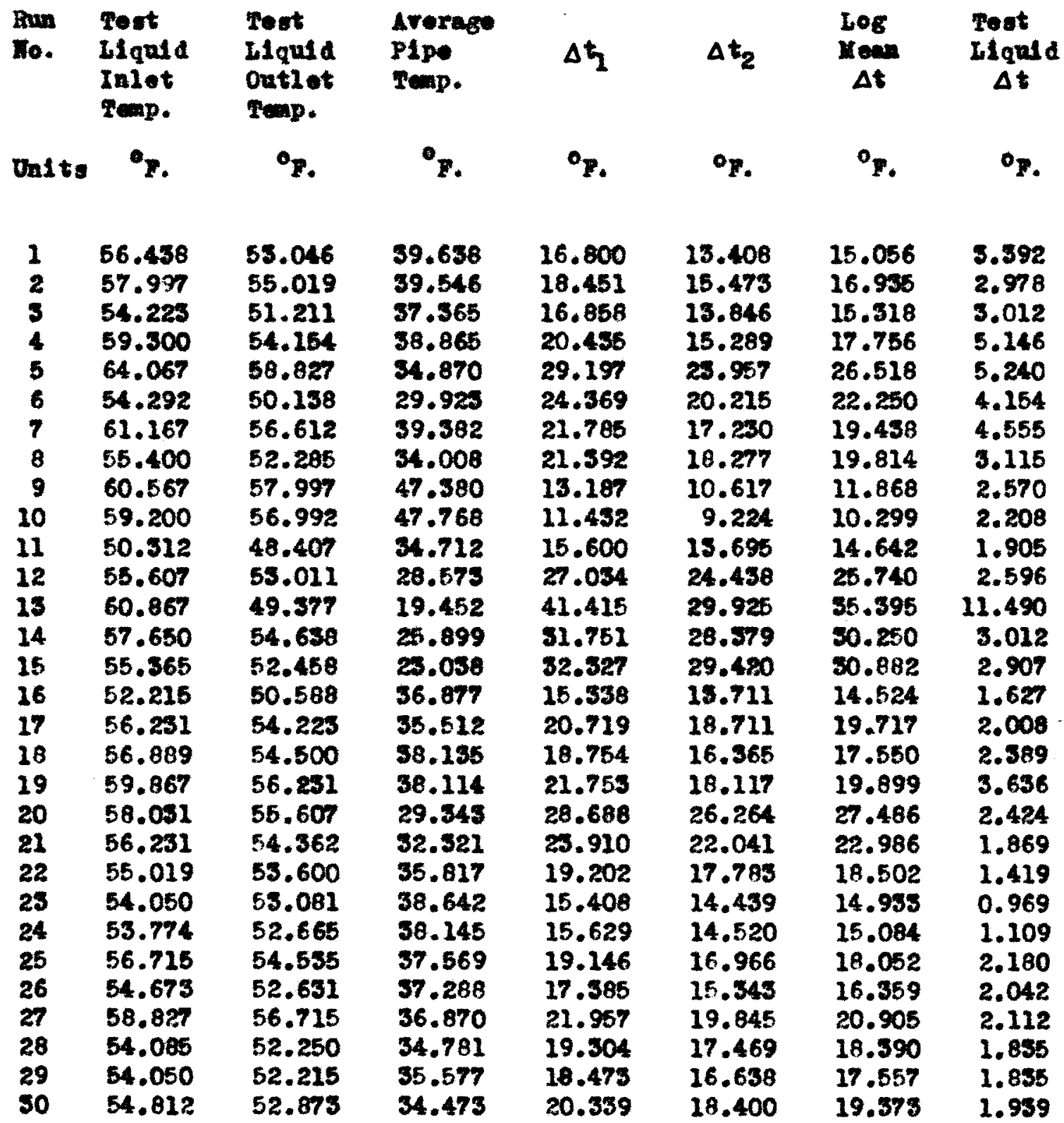


Table II

BRAT TRASF⿱ DATA

\begin{tabular}{|c|c|c|c|c|c|c|c|}
\hline $\begin{array}{l}\text { Bun } \\
\text { no. }\end{array}$ & $\begin{array}{l}\text { Tent } \\
\text { Liquid } \\
\text { Inlet } \\
\text { remp. }\end{array}$ & $\begin{array}{l}\text { Pest } \\
\text { Ilquid } \\
\text { outlet } \\
\text { Teap. }\end{array}$ & $\begin{array}{l}\text { Average } \\
\text { Plpe } \\
\text { reap. }\end{array}$ & $\Delta t_{1}$ & $\Delta t_{2}$ & $\begin{array}{l}L 08 \\
\text { Yoan } \\
\Delta t\end{array}$ & $\begin{array}{l}\text { Toot } \\
\text { Liquid } \\
\Delta t\end{array}$ \\
\hline Unito & ${ }^{\circ} \boldsymbol{Y}$. & ${ }^{0} p$ & ${ }^{\circ}$. & ${ }^{\circ}{ }_{F}$ & ${ }^{\circ} \mathbf{F}$ & ${ }^{\circ}{ }_{1}$ & ${ }^{\circ} \mathrm{F}$. \\
\hline $\begin{array}{l}31 \\
32 \\
33 \\
34 \\
35 \\
56 \\
57 \\
38 \\
59 \\
40 \\
41 \\
42 \\
43 \\
44 \\
45 \\
46 \\
47 \\
48 \\
49 \\
50 \\
51 \\
52 \\
55 \\
54 \\
55 \\
56 \\
57 \\
58 \\
59 \\
60\end{array}$ & $\begin{array}{l}54.742 \\
55.123 \\
50.830 \\
62.853 \\
61.067 \\
62.267 \\
62.735 \\
64.000 \\
65.400 \\
66.600 \\
65.933 \\
62.300 \\
60.767 \\
59.567 \\
57.892 \\
57.096 \\
56.127 \\
55.780 \\
55.780 \\
54.950 \\
54.673 \\
54.569 \\
66.700 \\
65.167 \\
63.833 \\
63.033 \\
62.133 \\
61.353 \\
60.767 \\
61.535\end{array}$ & $\begin{array}{l}52.907 \\
53.184 \\
50.035 \\
61.400 \\
57.798 \\
58.862 \\
59.100 \\
59.600 \\
61.533 \\
61.835 \\
60.200 \\
57.546 \\
56.785 \\
55.607 \\
54.396 \\
53.566 \\
52.977 \\
52.250 \\
51.869 \\
50.796 \\
50.415 \\
50.277 \\
61.100 \\
60.935 \\
60.200 \\
60.000 \\
59.500 \\
59.167 \\
50.862 \\
59.858\end{array}$ & $\begin{array}{l}33.666 \\
32.459 \\
36.855 \\
45.801 \\
46.811 \\
46.167 \\
47.085 \\
47.359 \\
46.352 \\
45.686 \\
32.757 \\
32.181 \\
32.373 \\
33.643 \\
34.574 \\
35.077 \\
35.691 \\
34.505 \\
34.544 \\
35.325 \\
36.126 \\
36.902 \\
35.747 \\
37.045 \\
38.599 \\
41.519 \\
42.930 \\
44.522 \\
47.175 \\
49.749\end{array}$ & $\begin{array}{l}21.076 \\
22.664 \\
13.975 \\
17.032 \\
14.256 \\
16.100 \\
15.648 \\
16.661 \\
19.048 \\
20.914 \\
33.176 \\
30.119 \\
28.394 \\
25.924 \\
23.318 \\
22.019 \\
20.436 \\
21.275 \\
21.136 \\
19.627 \\
18.557 \\
17.667 \\
50.953 \\
28.122 \\
25.234 \\
21.514 \\
19.203 \\
16.811 \\
13.592 \\
11.784\end{array}$ & $\begin{array}{l}19.241 \\
20.725 \\
13.180 \\
15.599 \\
10.977 \\
12.695 \\
12.015 \\
12.261 \\
15.181 \\
16.147 \\
27.445 \\
25.365 \\
24.412 \\
21.964 \\
19.622 \\
18.489 \\
17.286 \\
17.745 \\
17.225 \\
15.473 \\
14.299 \\
13.375 \\
25.353 \\
23.988 \\
21.601 \\
18.481 \\
16.570 \\
14.645 \\
11.687 \\
10.084\end{array}$ & $\begin{array}{l}20.165 \\
21.702 \\
13.587 \\
16.321 \\
12.558 \\
14.345 \\
13.766 \\
14.363 \\
17.067 \\
16.447 \\
30.249 \\
27.702 \\
26.380 \\
23.910 \\
21.544 \\
20.235 \\
18.836 \\
19.476 \\
19.133 \\
17.485 \\
16.352 \\
15.437 \\
28.088 \\
25.974 \\
23.394 \\
19.976 \\
17.872 \\
15.719 \\
12.628 \\
10.923\end{array}$ & $\begin{array}{l}1.835 \\
1.959 \\
0.795 \\
1.435 \\
3.279 \\
3.405 \\
3.633 \\
4.400 \\
3.867 \\
4.767 \\
5.733 \\
4.754 \\
3.982 \\
3.960 \\
3.496 \\
3.550 \\
3.150 \\
3.530 \\
3.911 \\
4.154 \\
4.258 \\
4.292 \\
5.600 \\
4.234 \\
5.635 \\
3.035 \\
2.635 \\
2.166 \\
1.905 \\
1.700\end{array}$ \\
\hline
\end{tabular}




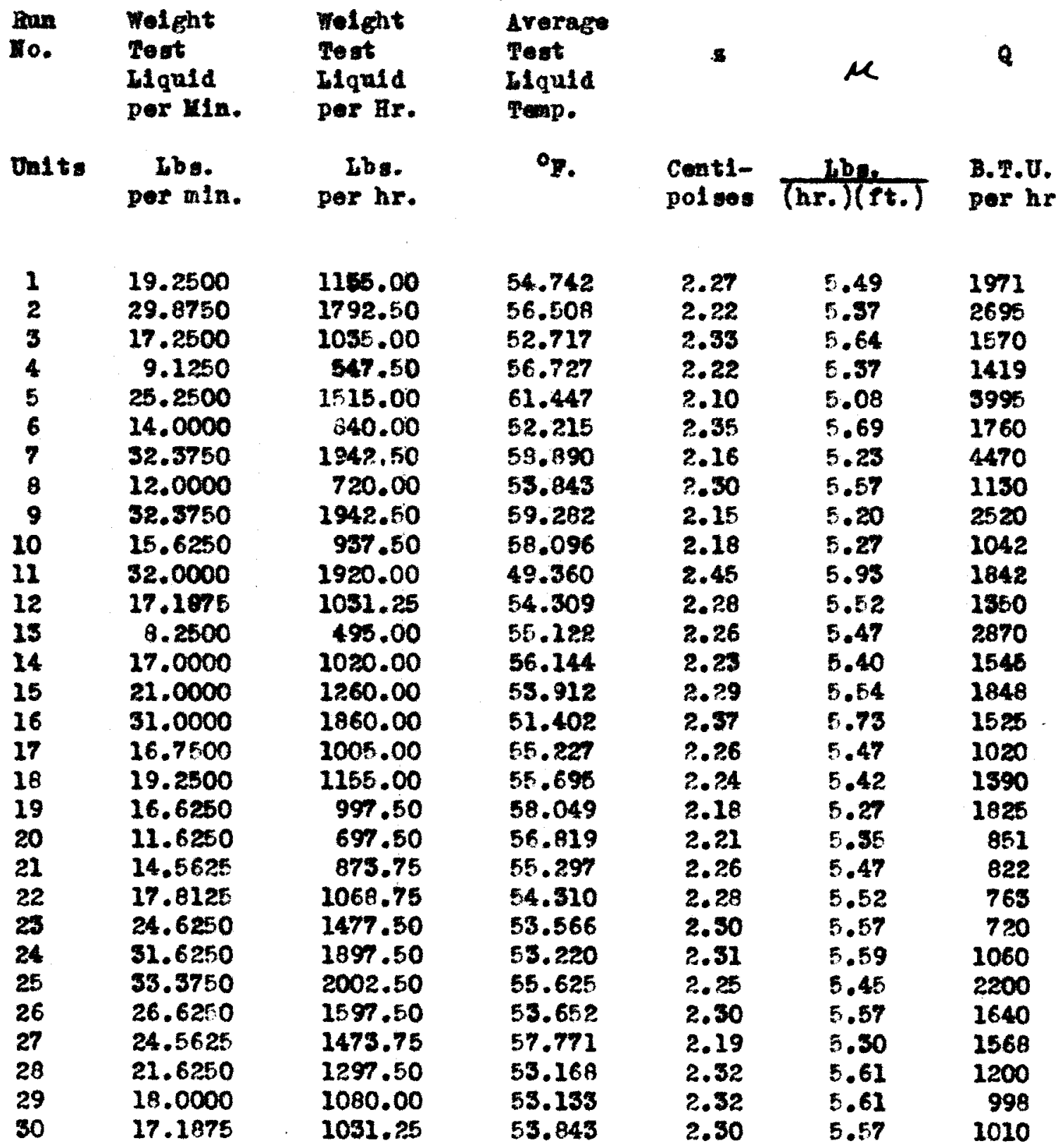




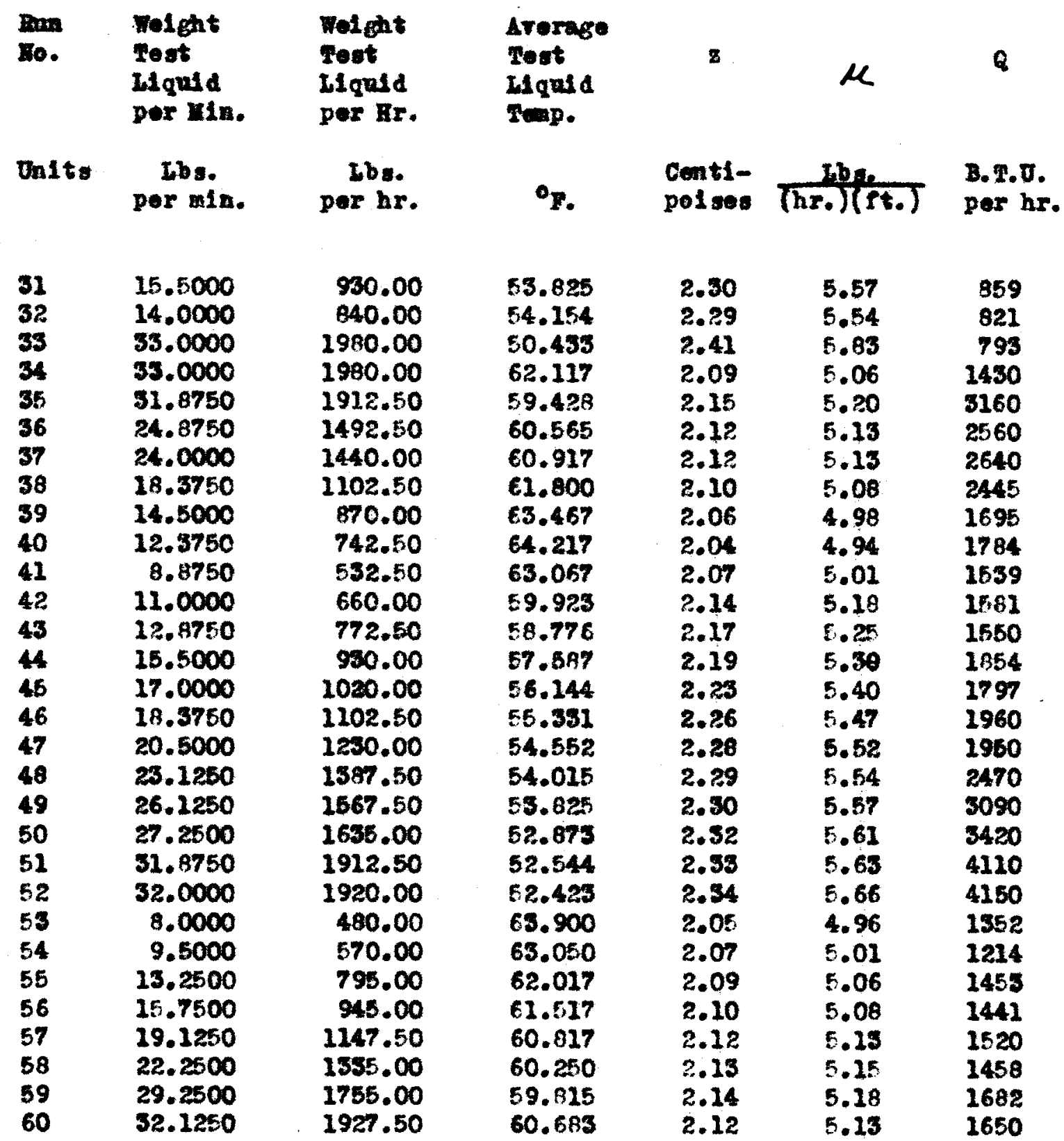




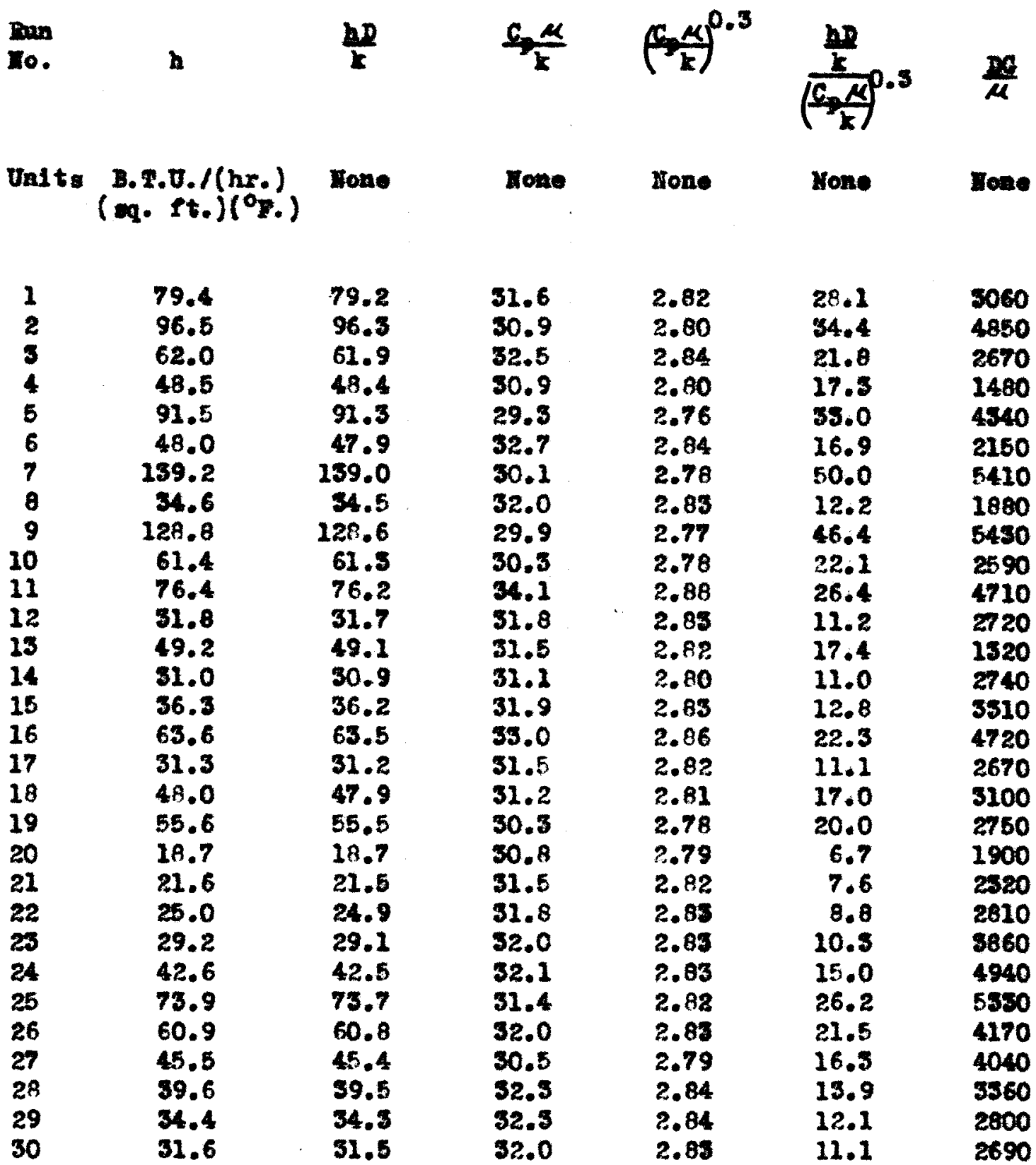




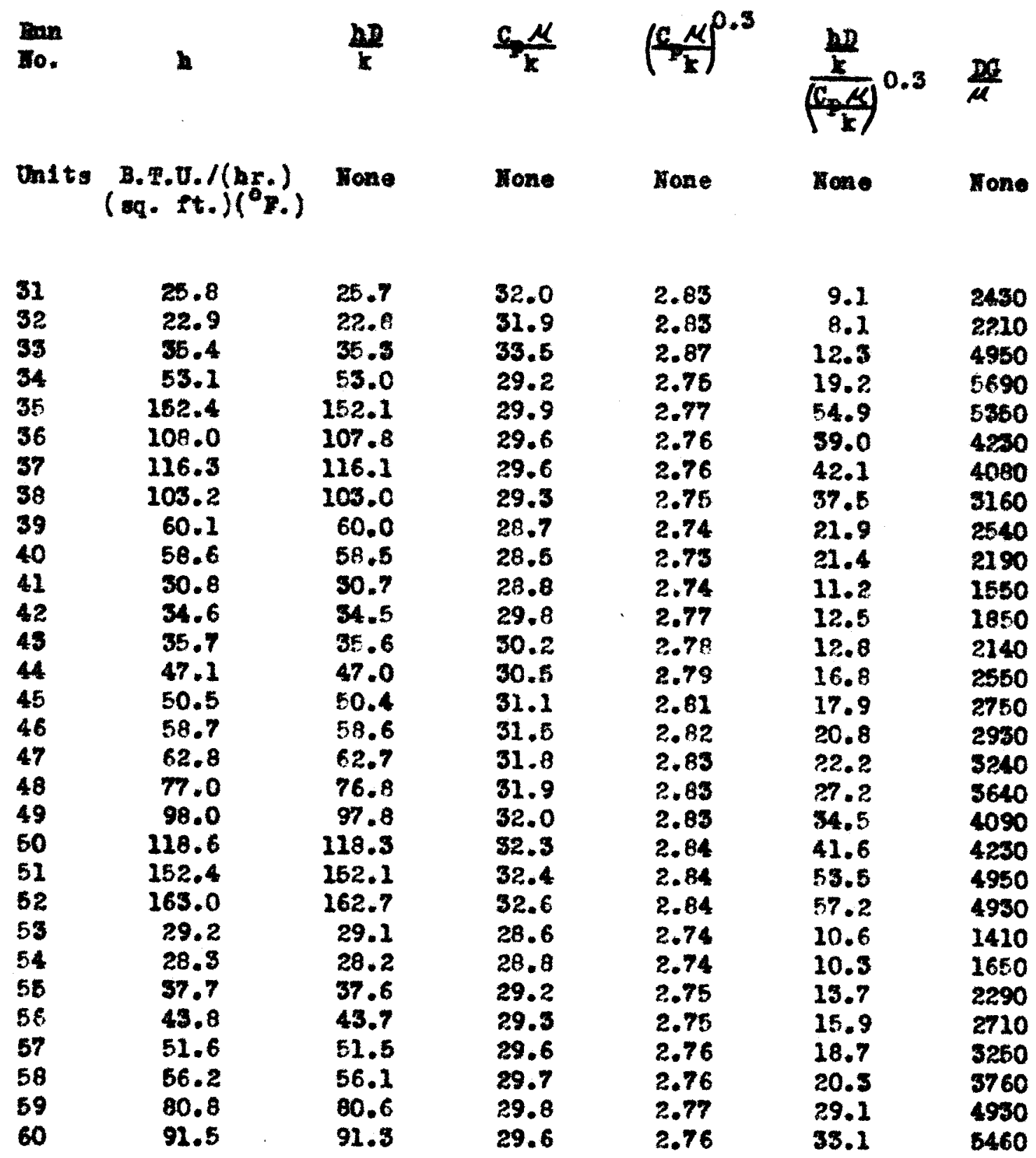


hare unod the teuperstrures at the ends of the plpe in the caloulation of the eoofficlents, bat sinee, In the prosent investiention, the temperature sl we of the refrlgereting fluid ont bide the plpe was rery all. and tue largely to heat 10 sses in the apparetus, thls arerage tempernture was asmed to represent constant condstions along the length of the pipe, and wa further assaned to be autable for the calculation of arerago coorficiente. $\Delta t_{2} 18$ the afferonce between the teot Ilquid inlet temporature and the arerage pipe tempersture, wile $\Delta t_{2}$ is the alfference between the test Ilquid outlet temprature and the arervere pipe temperature. The logarl thate moen temperature difference is the logard thalc mean of $\Delta t_{1}$ and $\Delta t_{2}$. The test 11 quid $\Delta t$ ropresonts the decrease in temperature brought about by paseage through the test section. The

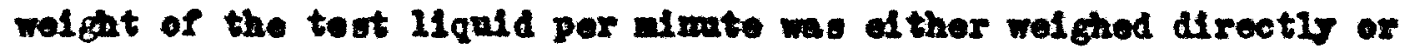
el se obtained iy a Inple matiplication, nen the porlod orer what the sample was collested was less than a mimute. the wolght of test 11quid per hour was obtalned by multiplying the wolght per almute by 60 . The average test IIquid temperature is the arerage of the Inlet and outlet tenperatures, and was calculated in order that an arorage viscosit could be obtalned. The riseosity in centipol ses was taken from the curve at the average test 11quid teaperature, while the absolute ria cosity was obtalned by conversion to pounds per foot-hour.

The quantlty of heat transforred per hour was calculated as the product of the temperature change, the specific hest, and the welght per hour. The film coefficient, $h$, was caloulated by uso of fowton's law- $Q / \theta=h \Delta \Delta t ;$ in wheh $Q / \theta$ is the quantity of heat trangforred per hour, $h$ is the film coefflelent, $A$ is the heat trangfer area, and $\Delta t$ 
1s the temperature differential. In this case, the aren was taken as the Inglde area of exactly six foet of standard one-inch pipe, and the logarl thale moan temperature differential wa used as $\Delta$ t.

The ralues of the huselt and Prandtl mubers were calculated ugline the filn coeffielents and the physical properties of the flud. The Bequolds nuber, as proviously stated, wa calculated diroctly from the wolght rate of $\mathrm{fow}$ as $4 \pi / \pi \mathrm{p} \mu$ more $\mathrm{w}$ and $\mu$ hare the units pounds per hour and pounds per foot-hour respectively.

$$
4 \text { sample calculation, neine the data of fon No. } \frac{3}{2} \text { is as }
$$

follows:

$\Delta+2:$

$\operatorname{Lex} \operatorname{Men} \Delta t$$$
\Delta t_{2}:
$$

$$
\begin{aligned}
\Delta t_{1} & =t_{1}-t \\
& =62.833-46.801 \\
\Delta t_{1} & =17.032^{\circ} \mathrm{F} . \\
\Delta t_{2} & =t_{2}-t \\
& =61.400-45.801 \\
\Delta t_{2} & =15.599^{\circ} \mathrm{F} . \\
\Delta t_{1} & =\frac{\Delta t_{2}-\Delta t_{2}}{1 \mathrm{~s} \frac{t_{2}}{\Delta t_{2}}} \\
& =\frac{17.032-15.599}{2.303108 \frac{17.032}{15.599}} \\
\Delta t_{\mathrm{t}} & =16.321^{\circ} \mathrm{F} .
\end{aligned}
$$

Rentilautd $\Delta t: \quad \Delta t=t_{1}-t_{2}$

$$
=62.838-61.400
$$$$
\Delta t=1.483^{\circ} \mathrm{F} \text {. }
$$

(Terms are dofined in the 11 st of ambols.) 
Fiset Rate of Flar: $\quad W=W \times 60$ mere $w$ is the welght of $=33.00 \times 60$ test liguid per mimate $v=1980.00 \mathrm{Ibs} . \mathrm{hr}$.

Arerese Tert Iougd Temperature:

$$
\begin{aligned}
t_{2} & =\frac{t+t_{0}}{2} \\
& =\frac{62.838+61.100}{2} \\
t_{\mathrm{z}} & =62.117^{\circ} \mathrm{F}
\end{aligned}
$$

Abrolute Vicesitr: $\quad \mu=2 \times 2.42$

$=2.09 \times 2.42$

$\mu=5.06$ Ibs./ft.-hr.

Fest Trengferred:

$$
\begin{aligned}
Q & =w \times \Delta t \times C_{p} \\
& =1980.0 \times 1.453 \times 0.504 \\
Q & =1430 \text { B.T.U.Mr. }
\end{aligned}
$$

21] cenfletent: $\quad Q / \theta=\mathbf{L} \times \mathbf{\Delta} \times \Delta t$

$$
h=\frac{Q}{\Delta x \Delta t}
$$

$$
=\frac{1430}{1.65 \times 16.321}
$$

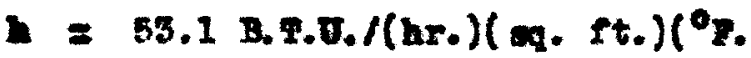

Inanelt raber:

$$
\operatorname{ma}=\frac{2 x}{\mathbf{z}}
$$

$$
=\frac{5 \times .1 \times 0.0874}{0.0876}
$$

wu $=55.0$

Erenitl Mraber:

$$
\begin{aligned}
\text { Pr } & =\frac{c x}{k} \\
& =\frac{0.504 \times 5.06}{0.0675} \\
\text { Pr } & =29.2
\end{aligned}
$$




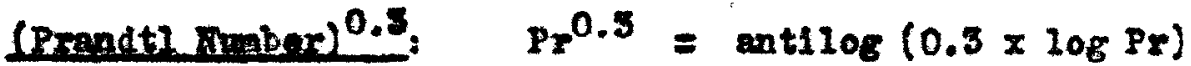

$$
\begin{aligned}
& =\operatorname{ant1108}(0.3 \times 10829.2) \\
& \operatorname{Pr}^{0.5}=2.75
\end{aligned}
$$

Batio of Inselt to Prandt I number:

$$
\begin{aligned}
\frac{k n}{\left(\frac{k}{k}\right)^{0.3}} & =\frac{5.0}{2.75} \\
& =19.2
\end{aligned}
$$

Bamaldin nubor:

$$
\begin{aligned}
\text { Re } & =\frac{4 \times \pi}{\pi \times D \times \mu} \\
& =\frac{4 \times 1980.00}{3.1416 \times 0.0674 \times 5.06} \\
R_{0} & =5690
\end{aligned}
$$

the experimental date Is show Grapleally by curre I, page 58,

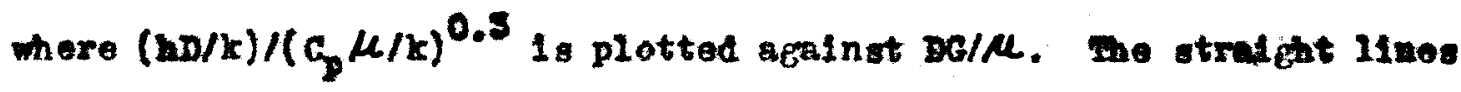
ropresent the ofttus and Beelter equation and the epirieal oquation derived from the present data. The supplenentary points are taken frea the kerosene data of sherrood and Petrie.

The method of least equares was used to obtain the oquation of the straight line beat correlating the data, and the equation obtained was:

$$
\frac{m}{L}=0.0121\left(\frac{n t}{\mu}\right)^{0.915}\left(\frac{G_{x}}{k}\right)^{0.5}
$$

as sompared of the Ditus and Boelter equation:

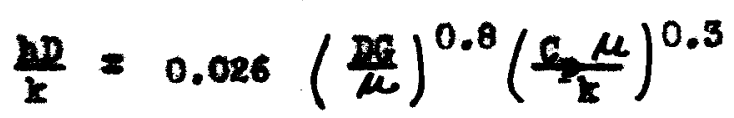

The coerricient of correlation, which is a measure of the tenienes of two rarlables to rary together, was found to be 0.652 . w s compared of th - ralne of 1.000 for perfect correlation. 


\section{EMpIRICAK Equations}

30

20

$$
\frac{\frac{h D}{K}}{\left(\frac{C_{\rho} \mu}{K}\right)^{0.3}}
$$

10

9

8

7

6

5

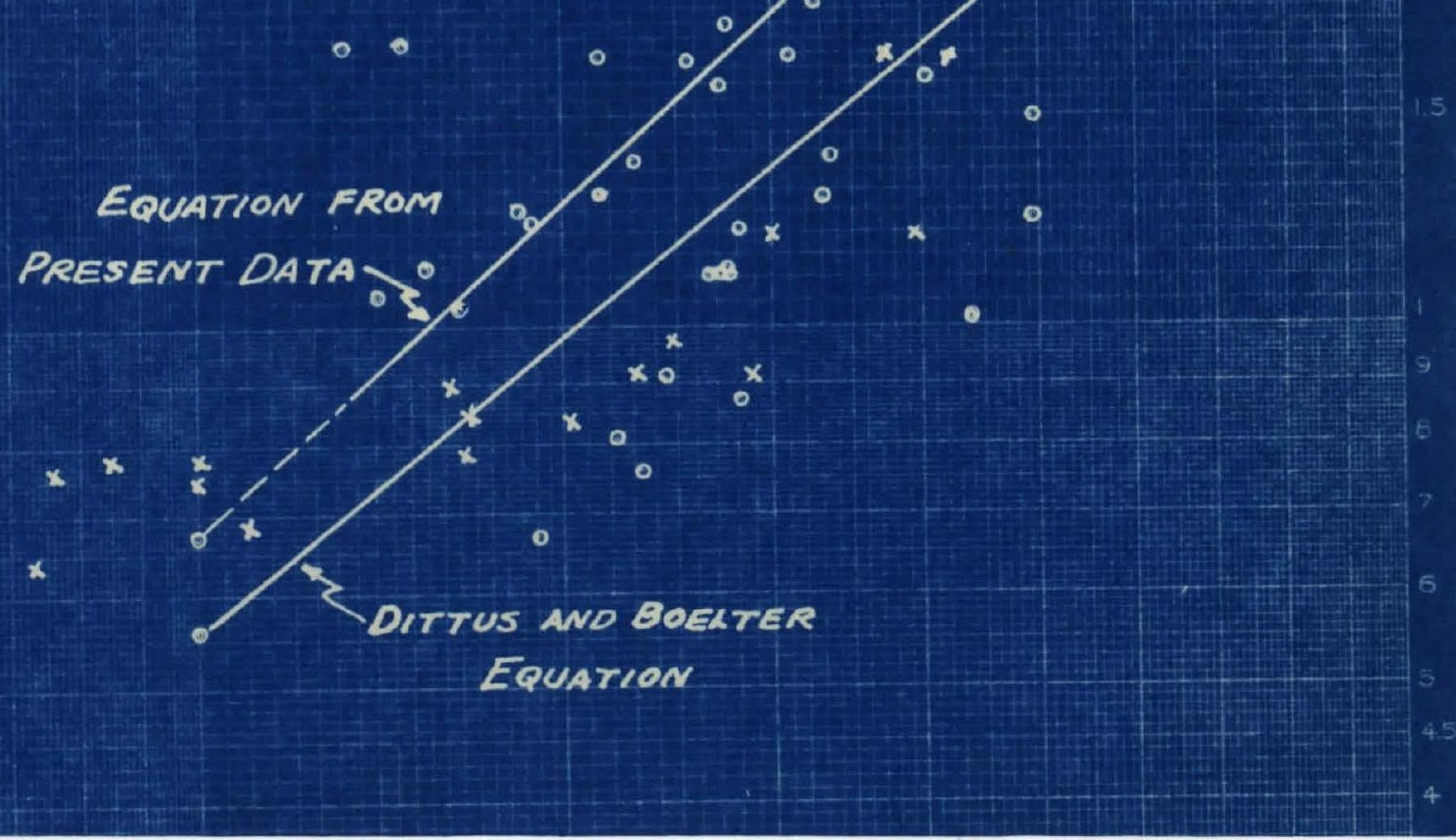


* Sherwooo na petrie 
IV. concurstors 
Ifeat trangfer coeffleionts were deternined for Rownolds numbers ranging from abcut 1500 to 5500 . The groups. $(\mathrm{hD} / \mathrm{k}) /\left(c_{\mathrm{p}} \mu \mathrm{k}\right)^{0.3}$ wero plotted agalast the Rernolds mubers, and the method of lea st squres was uged to obtain the equation of the best gtraigat Iine through the polnts. It was found that the data covid be correlated by use of the equation:

$$
\frac{n D}{x}=0.0121\left(\frac{\mathrm{na}}{\mu}\right)^{0.915}\left(\frac{g_{n} \mu}{k}\right)^{0.3}
$$

wich compares very farorably od the Dittus and Boelter equation:

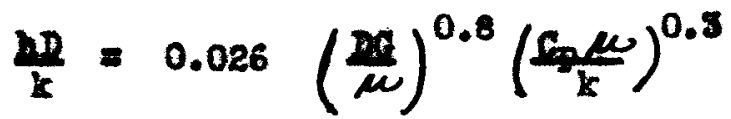

Is predieted by Sherwood and Petrie. the slope of the emplrical curve Is Ereater than 0.8 , by about $14 \%$.

The value of the coefficlent of correlation, 0.652, indicates that the Musselt equation way be satlofactorily used for the correlation of heat trangfor data in the riscoas and eritleal reglons, a well as in regiong of tarbulent flow. It wa found that the present data could not be sat1 sfactorlis correlated by means of the Graetz relation.

The moat accurate experimental data is obtalned only when - crullibrium condtions are ostabli shed before the readings are taken. The instellation of an orfle meter in the test Ilquid return IIne would result in ereater accuracy in the determination of the rate of Now. A check on the quant1 ty of hest transferred could be obtalned If the rate of flow and the temperatare change of the refrlgerant were deternined. 
The authos is Indebted to Wil son $\mathrm{A}$. Barnes, wo alded Wth the experimental work in this investigation. 
BT KLI OFRAPH 
1. Browe and Hinger: Thesi is in Chemical Buglneoring. Untrargity of Lord ovi11e. 1935.

2. Brome; Thesis in Chenlcal inglnoering; University of Loularilie. 1936

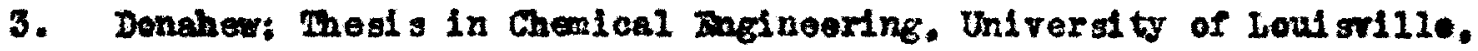
1986.

4. Mehdems and Prost: Refrietrating Mg.. 10, Ko. 9, 1924.

5. Lawrence and sherwood: Ind. 5ng. Crem., 23, 301, 1931.

6. Lorr's and thitman: Ind. Bng. Chem., 20, 234, 1926.

7. Rlce: Ind. Ing. Chem. 16, 460, 1924.

8. Mttus and Boelter: Onlv. Cal1f. Pub. Ent.. 2, 443, 1930.

9. Sherrood and Petrie; Ind. Cher.., 24, 736, 1932.

10. Sult th; Trans. Amer. Inst. Chen. Ine., 33, 63, 1935.

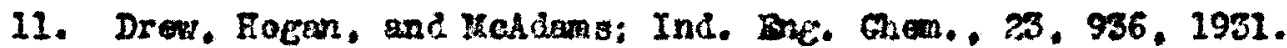

12. Sherwood, Hiley, and Wangeon; Ind. Hge. Chem., 24, 279, 1932.

23. Badger and HcCabe: Hements of Chemical Pnglnearing. McGrar-HIII Company. 1936.

14. UaAdam Es Heat Trangniaston. MeGraw-H111 Company. 1933. 
APPEITX 
Poble III

DISTILLATOR RAMGRS OF BOCTIT

\begin{tabular}{|c|c|c|}
\hline $\begin{array}{l}\text { Pereent } \\
\text { m gt111ed }\end{array}$ & $\operatorname{Somple}_{\text {Sample }}$ & $\begin{array}{l}\text { Uoed } \\
\text { Bample }\end{array}$ \\
\hline 0 & 520 & 332 \\
\hline 10 & 367 & 368 \\
\hline 20 & $\$ 76$ & 384 \\
\hline 30 & 386 & 407 \\
\hline 40 & 398 & 424 \\
\hline 50 & 424 & 459 \\
\hline 60 & 448 & 455 \\
\hline 70 & 466 & 471 \\
\hline 80 & 484 & 490 \\
\hline 90 & 509 & 510 \\
\hline
\end{tabular}




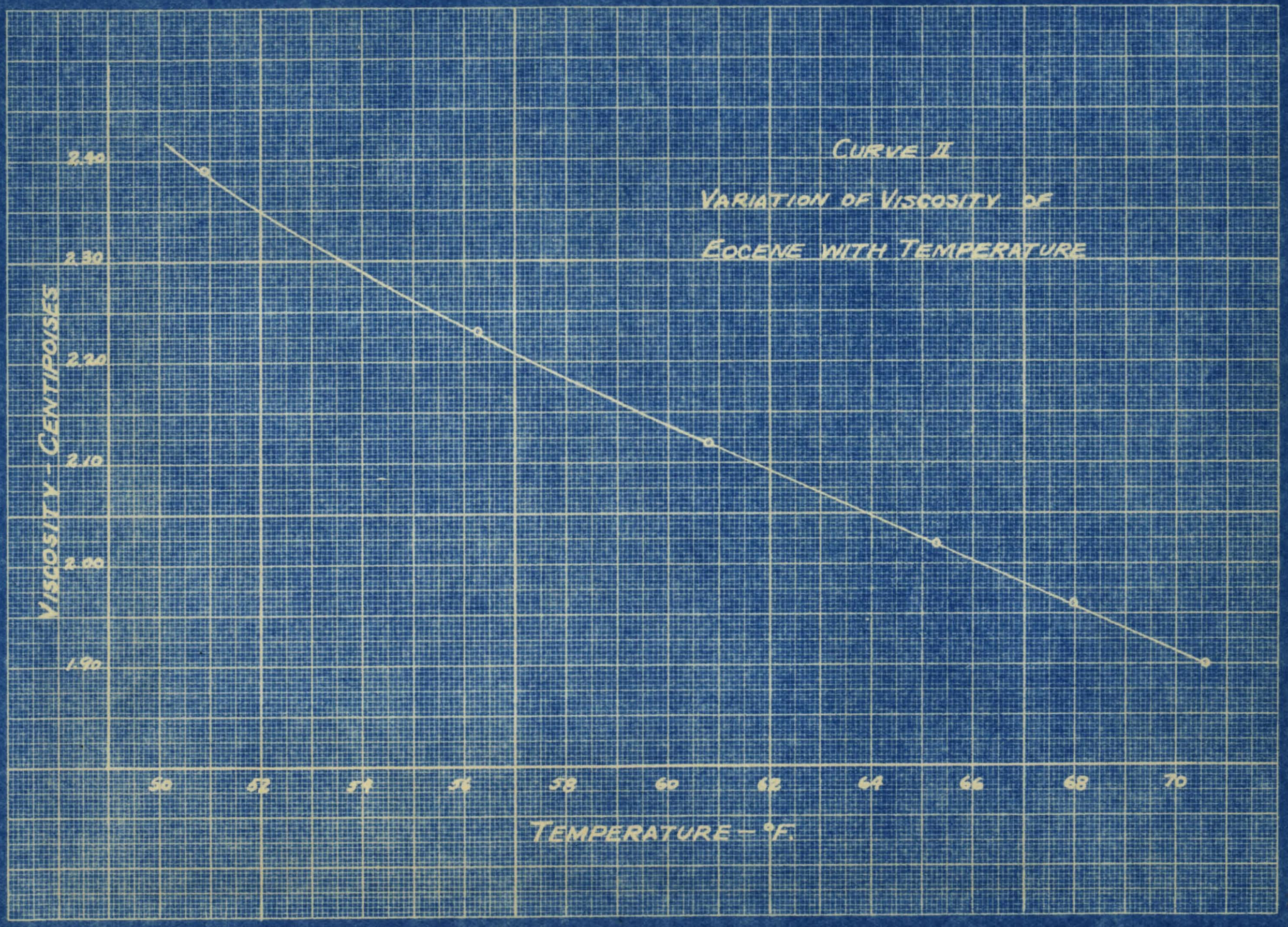

